化への第一の障害が取除かれたものと考朰らる。さら に $c$ 軸をそろえられるような加圧方法, キューリ点をも う少し(出来れば $80^{\circ} \mathrm{C}$ ぐらいまで) 上昇させられるよ うな組成の研究など，残された問題はまだ多いが，それ らについては次の機会に述べることにしたい。

\section{文献}

1) E. Dönges : Z. anrog. allgen. chem., 263, 112 (195j) ibid. 263, 280 (1950) ibid. 265, 56 (1951)

2) R. Nitsche and W. Merz: J. Phys. Chem. Solids, 13, 154 (1960)

3) R. Kern : ibid. 23, 249 (1962)

4) E. Fatuzzo et al : Phys. Rev. 127, 2036 (1962)

5) D. Berlincourt et al: Appl. Phys. Letters, 4, 61 (1964)
6) R. Kern : ibid. 23, 249 (1962)

R. Nitsche et al. : Appl. Phys. Letters, 4, 210 (1964)

7) T. Mori and H. Tamura: T. Phys. Soc. Japan, 19 1247 (1954)

8) E. Fatuzzo et al : Phys. Rev. 127 No. 6 (1962).

9）川久保：日本物理学会誌 20，267 (1965)

10) 岡崎, 高橋: 第 5 回 窯業基礎討論会 No. 23 (1967 年 1 月).

11）岡, 菊地, 森, 沢口: 日本物理学会第 20 回年会 (1965 年 10 月）講演および同予稿集（物性関係 II ）.

12) R. Nitsche et al : Appl. Phys. Letters, 4, 210(1964).

13) IRE Standards on Piezoelectric Crystals : Measurements of Piezoelectric Ceramics, 1961.

(7/1/1967 受付)

[研究速報］

\title{
Effects of Minor Additions on the Stress Build-up in a Sodium Borate Glass by Ultra-violet Irradiation
}

\author{
(Stress in Glass Caused by Ultra-violet Irradiation Part 11) \\ By \\ Kazuo ŌOKA, Tomoyoshi SAITŌ, and Tōru KISHII \\ (Tokyo Shibaura Electric Co., Kawasaki, Japan)
}

Stress is built up in alkali borate and borosilicate glasses by ultra-violet irradiation ${ }^{1)}$. The values of the stresses are strongly affected by small addition of some kinds of ions in the glasses ${ }^{2)}$. Effects of additions of many kinds of ions in a sodium borate glass were examined with the results described below.

Glasses of the batch composition $x \mathrm{R}_{m} \mathrm{O}_{n}$. $20 \mathrm{Na}_{2} \mathrm{O} \cdot(80-x) \quad \mathrm{B}_{2} \mathrm{O}_{3}$ or $x \mathrm{Na}_{p} \mathrm{X} \cdot 20 \quad \mathrm{Na}_{2} \mathrm{O} \cdot(80-$ $x) \mathrm{B}_{2} \mathrm{O}_{3}$ in mol\% were prepared. Here, $\mathrm{R}$ and $\mathrm{X}$ indicate cations and anions, respectively. The glasses were melted in a platinum crucible in an electric furnace from reagent grade chemicals $\left(\mathrm{Na}_{2} \mathrm{CO}_{3}, \mathrm{HBO}_{3}, \cdots \cdots\right)$. They were formed into tetragonal columns $(15 \times 10 \times 5 \mathrm{~mm})$ with polished surfaces.

The columns were then exposed to ultra-violet light for $1000 \mathrm{hr}$. The light source was a $400 \mathrm{~W}$ mercury discharge lamp made of silica glass (15 $\phi \times 150 \mathrm{~mm}$ ). The distance between the surfaces of the columns and the axis of the lamp was 28 $\mathrm{mm}$. During irradiation, the columns were cooled by dry air flow. After irradiation, the stresses in the irradiated surfaces were examined photoelastically with a Toshiba precision strain meter. The results are given in Table 1. Stresses lower than about $20 \mathrm{~kg} / \mathrm{cm}^{2}$ were not conclusive owing to residual thermal stresses in the glass columns and they are indicated in the table with asterisks. The effects of additions are classified graphically in Fig. 1.

In the cases of $1 \sim 3$ mol\% addition, the results are summarized as follows: Stress is built up in glasses containing I a (alkali) and II a (alkaline earth) ions; $\mathrm{Vb}(\mathrm{P}, \mathrm{As}, \mathrm{Sb}$ and $\mathrm{Bi})$, $\mathrm{VIb}(\mathrm{S}$, Se and $\mathrm{Te}$ ) and $\mathrm{VIlb}$ (halogen) ions in glasses seem to supress the stress. Ions of heavier elements in the II b, III b and IVb groups supress the stress, but the ions of lighter elements do not.

Relations between the stress and the amounts of the additives seem complex: for example, 0.1 mol\% addition of the oxides of $\mathrm{Ce}, \mathrm{Pb}$ and $\mathrm{U}$ intensifys the stresses, but 3 mol $\%$ addition of those ions reduces or supresses the stresses.

Some kinds of additives, for example, $\mathrm{CuO}$, $\mathrm{GeO}_{2}$ and $\mathrm{Cs}_{2} \mathrm{O}$ (and also $\mathrm{CeO}_{2}, \mathrm{PbO}$ and $\mathrm{UO}_{2}$ ) distinctly intensify the stress. In the glasses containig $0.1 \mathrm{~mol} \%$ of $\mathrm{Cr}_{2} \mathrm{O}_{3}, \mathrm{MnO}$ and $\mathrm{CoO}$, stresses seemed to exist in the extremely thin surface layers, but at the present stage of the investigation this is not conclusive.

The authors proposed a theory on the struc- 
Table 1. Experimental results.

\begin{tabular}{|c|c|c|c|c|c|c|c|c|c|c|c|c|c|c|}
\hline $\begin{array}{l}\text { glass } \\
\text { No. }\end{array}$ & $\begin{array}{c}\mathrm{R}_{m} \mathrm{O}_{n} \\
\text { or } \mathrm{Na}_{p} \mathrm{X}\end{array}$ & $x$ & $\begin{array}{c}\text { stress } \\
\mathrm{kg} / \mathrm{cm}^{2}\end{array}$ & $\begin{array}{c}\text { raw } \\
\text { material }\end{array}$ & $\begin{array}{l}\text { glass } \\
\text { No. }\end{array}$ & $\begin{array}{c}\mathrm{R}_{m} \mathrm{O}_{n} \\
\text { or } \mathrm{Na}_{p} \mathrm{X}\end{array}$ & $x$ & $\begin{array}{l}\text { stress } \\
\mathrm{kg} / \mathrm{cm}^{2}\end{array}$ & $\begin{array}{c}\text { raw } \\
\text { material }\end{array}$ & $\begin{array}{l}\text { glass } \\
\text { No. }\end{array}$ & $\begin{array}{c}R_{m} O_{n} \\
\text { or } \mathrm{Na}_{p} \mathrm{X}\end{array}$ & $x$ & $\underset{\mathrm{kg} / \mathrm{cm}^{2}}{\text { strass }}$ & $\begin{array}{c}\text { raw } \\
\text { material }\end{array}$ \\
\hline 3 & $\mathrm{Li}_{2} \mathrm{O}$ & 3 & 35 & c & 29 & $\mathrm{CuO}$ & 0.1 & 210 & o & 55 & $\mathrm{Cs}_{2} \mathrm{O}$ & 3 & 150 & c \\
\hline 4 & $\mathrm{BeO}$ & 3 & 49 & o & 30 & $\mathrm{ZnO}$ & 3 & 72 & o & 56 & $\mathrm{BaO}$ & 3 & 49 & c \\
\hline 5 & $\mathrm{~B}_{2} \mathrm{O}_{3}$ & 3 & 50 & $\mathrm{HBO}_{3}$ & 31 & $\mathrm{Ga}_{2} \mathrm{O}_{3}$ & 3 & 52 & o & 57 & $\mathrm{La}_{2} \mathrm{O}_{3}$ & 3 & $*$ & o \\
\hline 9 & $\mathrm{NaF}$ & 3 & $*$ & $\mathbf{n}$ & 32 & $\mathrm{GeO}_{2}$ & 3 & 177 & o & $58-1$ & $\mathrm{CeO}_{2}$ & 0.1 & 230 & o \\
\hline 11 & $\mathrm{Na}_{2} \mathrm{O}$ & 3 & 64 & c & 33 & $\mathrm{As}_{2} \mathrm{O}_{5}$ & 3 & $*$ & o & $58-2$ & $\mathrm{CeO}_{2}$ & 3 & 30 & o \\
\hline 12 & $\mathrm{MgO}$ & 3 & 52 & c & 34 & $\mathrm{SeO}_{z}$ & 1 & * & $\mathrm{Na}_{2} \mathrm{SeO}_{3}$ & 60 & $\mathrm{Nd}_{2} \mathrm{O}_{3}$ & 0.1 & * & o \\
\hline 13 & $\mathrm{Al}_{2} \mathrm{O}_{3}$ & 3 & $*$ & h & 35 & $\mathrm{NaBr}$ & 3 & * & $\mathrm{n}$ & 63 & $\mathrm{Eu}_{2} \mathrm{O}_{3}$ & 0.1 & 80 & o \\
\hline \multirow{2}{*}{14} & \multirow{2}{*}{$\mathrm{SiO}_{2}$} & \multirow[t]{2}{*}{3} & \multirow{2}{*}{50} & \multirow{2}{*}{$\begin{array}{l}\text { powder of } \\
\text { rock crystal }\end{array}$} & 37 & $\mathrm{Rb}_{2} \mathrm{O}$ & 3 & 79 & c & 73 & $\mathrm{Ta}_{2} \mathrm{O}_{5}$ & 3 & $*$ & o \\
\hline & & & & & 38 & $\mathrm{SrO}$ & 3 & 65 & c & 74 & $\mathrm{WO}_{3}$ & 0.1 & 36 & o \\
\hline 15 & $\mathrm{P}_{2} \mathrm{O}_{5}$ & 3 & * & o & $39-1$ & $\mathrm{Y}_{2} \mathrm{O}_{3}$ & 0.1 & 40 & o & 81 & $\mathrm{Tl}_{2} \mathrm{O}$ & 3 & $*$ & o \\
\hline 16 & $\mathrm{Na}_{2} \mathrm{~S}$ & 3 & * & $\mathrm{n}$ & $39-2$ & $\mathrm{Y}_{2} \mathrm{O}_{3}$ & 1 & $*$ & o & $82-1$ & $\mathrm{PbO}$ & 0.1 & 210 & o \\
\hline 17 & $\mathrm{NaCl}$ & 3 & $*$ & $\mathrm{n}$ & 40 & $\mathrm{ZrO}_{2}$ & 3 & $*$ & o & $82-2$ & $\mathrm{PbO}$ & 0.5 & 45 & o \\
\hline 19 & $\mathrm{~K}_{2} \mathrm{O}$ & 3 & 59 & c & 41 & $\mathrm{Nb}_{2} \mathrm{O}_{5}$ & 3 & $*$ & 0 & $82-4$ & $\mathrm{PbO}$ & 3 & $*$ & o \\
\hline 20 & $\mathrm{CaO}$ & 3 & 30 & c & 42 & $\mathrm{MoO}_{3}$ & 0.1 & * & o & 83 & $\mathrm{Bi}_{2} \mathrm{O}_{3}$ & 3 & $*$ & o \\
\hline 22 & $\mathrm{TiO}_{2}$ & 3 & $*$ & o & 47 & $\mathrm{Ag}_{2} \mathrm{O}$ & 0.1 & $\dagger$ & o & 90 & $\mathrm{ThO}_{2}$ & 0.1 & $*$ & o \\
\hline 23 & $\mathrm{~V}_{2} \mathrm{O}_{5}$ & 0.1 & $\S$ & o & 48 & $\mathrm{CdO}$ & 3 & 46 & o & $92-1$ & $\mathrm{UO}_{2}$ & 0.1 & 160 & \\
\hline 24 & $\mathrm{Cr}_{2} \mathrm{O}_{3}$ & 0.1 & $\S$ & o & 49 & $\mathrm{In}_{2} \mathrm{O}_{3}$ & 3 & $*$ & o & $92-1$ & $\mathrm{UO}_{2}$ & 3 & $*$ & $\mathrm{Na}_{3} \mathrm{U}_{2} \mathrm{O}_{7}$ \\
\hline 25 & $\mathrm{MnO}$ & 0.1 & $\S$ & o & 50 & $\mathrm{SnO}_{2}$ & 3 & * & o & & & & & \\
\hline 26 & $\mathrm{Fe}_{2} \mathrm{O}_{3}$ & 0.1 & 70 & o & 51 & $\mathrm{Sb}_{2} \mathrm{O}_{5}$ & 3 & * & o & I & $\mathrm{NaNO}_{3}$ & 3 & * & $\mathrm{n}$ \\
\hline 27 & $\mathrm{CoO}$ & 0.1 & $150 ? \S$ & o & 52 & $\mathrm{TeO}_{2}$ & 3 & * & o & II & $\mathrm{Na}_{2} \mathrm{SO}_{4}$ & 3 & * & $\mathrm{n}$ \\
\hline 28 & $\mathrm{NiO}$ & 0.1 & $\S$ & o & 53 & $\mathrm{NaI}$ & 3 & $*$ & $\mathrm{n}$ & III & $\mathrm{CH}_{3} \mathrm{COONa}$ & 3 & * & $\mathrm{n}$ \\
\hline
\end{tabular}

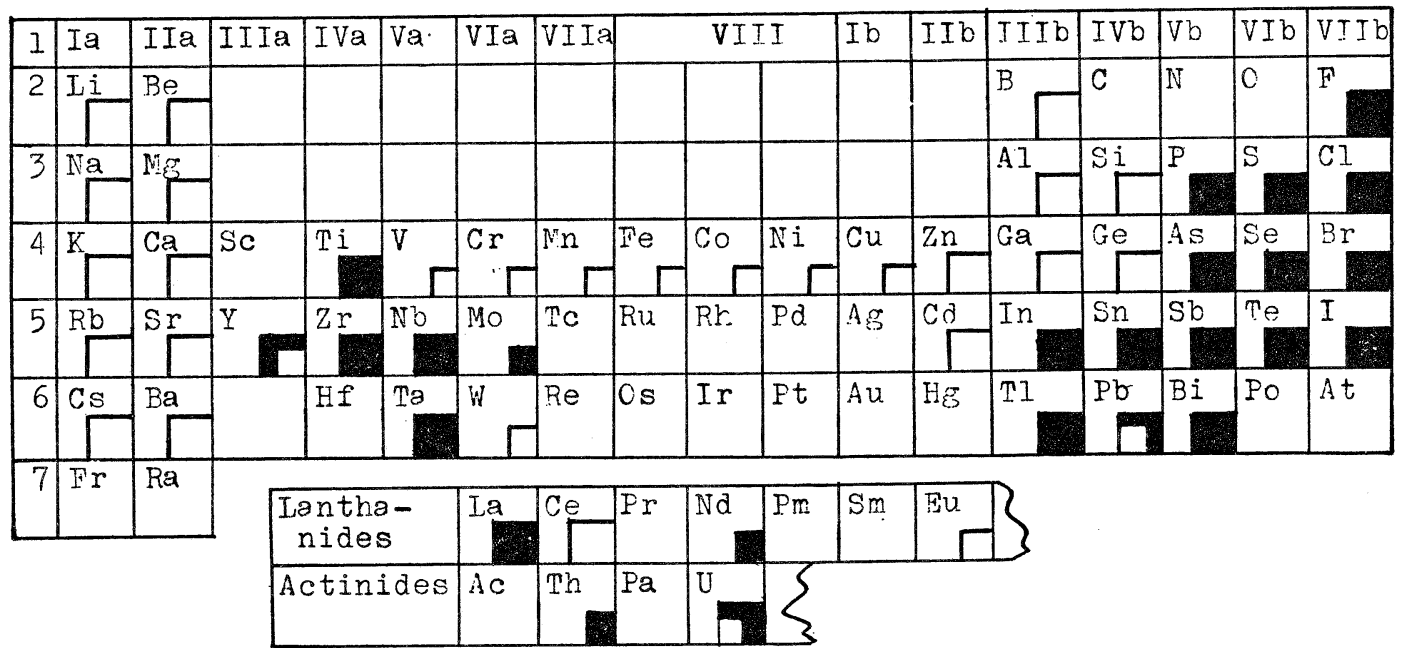

big white square : Stress is not supressed by 1 or $3 \mathrm{~mol} \%$ additon small white square : Stress is not supressed by $0.1 \mathrm{~mol} \%$ addition small black square : Stress is supressed by $0.1 \mathrm{~mol} \%$ addition

big black square : Stress is supressed by 1 or $3 \mathrm{~mol} \%$ addition

Fig. 1. Classification of the effect of additive ions.

tural change and stress build-up in borate glasses by ultra-violet irradiation ${ }^{3}$. The theory indicates that the important factors which enable the structural change in the glasses are (1). The comparatively loose packing of the glass network, (2). The peculiar behaviours of non-bridging oxygen ions in the network and (3). The ability of boron ions to change their valencies and coordination numbers.

Additive ions would fill vacant spaces in the network. Additive cations might either introduce non-bridging oxygen ions in the network and arrange the oxygen ions around themselves and form ionic bonds with the oxygen ions, or in some cases, affect the $\mathrm{BO}_{3} \leftrightarrow \mathrm{BO}_{4}$ equilibrium and advance or impede the change of coordination numbers of the boron ions. Additive anions might be replaced for non-bridging oxygen ions and aflect the activity of oxygen ions in the network. These behaviours of additive ions are expected to have some effects on the stress build-up, respectively.

On the other hand, from the photochemical point of view, the roles of additive ions would 
be classified as follows: 1. Internal filter which absorbs photon energy and dissipates it as thermal vibration of the network, 2. Activator or sensitizer which absorbs photon energy efficiently and converts it into the driving force for structural change of the network and 3. Deexcitation center which remove the energy of excited network and prevent the structural change of the network. Concentration of absorbed photon ener/gy caused by the activator might even provoke structural change by two-photon process. It should be noted that the relation similar to the heavy atom effects in photochemistry on quenching of excited states exists in III $\mathrm{b}$ and $\mathrm{IVb}$ groups in Table 1.

References

1) T. Kishii, K. Ōoka, J. Ceram. Assoc. Japan 72 [11-1] 193 (1964); Preprint of The Annual Meeting of The Intern. Congress on Glass (1966) p. 259.

2) K. Ōoka, T. Kishii, J. Ceram. Assoc. Japan 73 [4] 108 (1965).

3) K. Ōoka, T. Kishii, J. Ceram. Assoc. Japan 76 [1] 4 (1968).

[Received June 22, 1967]

\section{ERRATUM}

\section{The Effectiveness of Alkali Halide Media for the Process of $\mathrm{MgFe}_{2} \mathrm{O}_{4}$, $\mathrm{MgAl}_{2} \mathrm{O}_{4}$ and $\mathrm{MgCr}_{2} \mathrm{O}_{4}$ Formation}

\section{H. Yanagida and M. Atsumi}

J. Ceram. Assoc. Japan 75 [12] 349-352 (1967)

$\begin{array}{rcccc}\text { page } & \text { column } & \text { line } & \text { error } & \begin{array}{c}\text { right } \\ 350\end{array} \\ \text { left } & 25 & \text { media } & \text { medium } \\ 350 & \text { left } & 38 & \mathrm{Fe}_{2} \mathrm{O}_{\underline{4}} & \mathrm{Fe}_{2} \mathrm{O}_{3} \\ 350 & \text { light } & 5 & \text { methods } & \text { method } \\ 350 & \text { light } & 10 & \underline{\text { if not }} & \underline{\text { unless }} \\ 351 & \text { left } & 11 & \text { Media } & \text { Medium } \\ 351 & \text { left } & 21 & \text { midia } & \text { medium } \\ 351 & \text { light } & 24 & \text { graina } & \text { grains }\end{array}$

